\title{
Indian law for trial of juvenile - deterrent for crime or defence for criminals
}

\section{Opinion}

In India, The Juvenile Justice (Care and Protection of Children) Act, 2000 is applicable for those juveniles (children less than 18 years) who have committed a crime. This act has been amended in $2015 .{ }^{1}$ Under this act the juvenile in conflict with law (juvenile offender) is sentenced to a maximum 3 years in a remand home or a juvenile home (never in prison) if he has committed a petty or a serious offence. If the juvenile commits a heinous offence between 16-18 years of age then he can be given any punishment as per law. The objective of this act was "to consolidate and amend the law relating to juveniles in conflict with law and children in need of care and protection, by providing for proper care, protection and treatment by catering to their development needs, and by adopting a child friendly approach in the adjudication and disposition of matters in the best interest of children and for their ultimate rehabilitation through various institutions established under this enactment".

However, The Juvenile Justice Act has been misused consistently by individuals as their defence for crimes. As per this act, Age proof is required for those individuals who want to claim relief under this act. The age proofs acceptable under this act are $\mathrm{X}^{\text {th }}$ standard mark sheet or birth certificate or certificate of age from village sarpanch or executive magistrate. For a person who has no age proof a medical board is constituted for determining age. As by medical age determination only an age range can be provided, this age is used in his benefit by the alleged juvenile, The author came across a case where the individual committed crimes during 1986-92. During the trial in 2014 the accused claimed that he was a juvenile at the time of commission of the offence i.e. about 20 years back. In the age group of 25-40 years determining age is more difficult by the medical examination. The juvenile claimed the benefit of doubt in the said case.

Also it has been seen that the juveniles are being used by their guardians/peers for committing crimes. Recently in a case the author was tasked to determine the age of a juvenile who was caught stealing from the car. His modus operandi was that he used a slingshot (gulel) to break the window glass of cars and then stealing costly items from the car. Although he had been caught a number of times he was let off since he was a child (aged about 9-11 years). On further enquiry the

\author{
Volume 2 Issue 5 - 2016
}

\author{
Mohit Gupta \\ Department of Forensic Medicine,Vardhman Mahavir Medical \\ College, India
}

Correspondence: Mohith Gupta, Department of Forensic Medicine, Vardhman Mahavir Medical College \& Safdarjung hospital, New Delhi, India-I I0029, Email drmohitfm@gmail.com

Received: July 29, 2016 | Published: August 4, 2016

juvenile revealed that it was his father who asked him to steal while he himself stood at a distance observing everything. This is not a single instance of using a child for committing offence. Children are used for such crimes since they are let off with a simple verbal rebuke. Even law holds a lenient view and the child may be released after getting a warning. Even if child is punished it is usually for a period of 3 years and that too in a remand home. Hence, though the amendments in juvenile law are a positive step towards better law enforcement further introspection and amendments are required to prevent the misuse of this law. The law should be a deterrent to commission of crimes. It should not prove a defence for delinquent people.

\section{Acknowledgments}

None.

\section{Conflicts of interest}

None.

\section{References}

1. The Juvenile Justice (Care and Protection of Children) Act. The Controller of Publications, Delhi, India. 2015. 